\title{
Status of Narikoravar (A Type of Gypsy Community) Women Entrepreneur in Coimbatore, Tamil Nadu
}

\author{
S. Chandru ${ }^{1}$ and K. Thirumalaisamy ${ }^{2}$ \\ ${ }^{1}$ M. Phil Research Scholar, ${ }^{2}$ Head \\ ${ }^{1 \& 2}$ Department of Social Work, Sri Ramakrishna Mission Vidyalaya College of Arts \& Science \\ Coimbatore, Tamil Nadu, India \\ E-Mail: chandrucommerce@gmail.com, ktpragan@gmail.com
}

\begin{abstract}
The gypsies are indigenous people whose main occupation were hunting but are also considered as one of the greatest bandit communities in south India. The word gypsies is derived from Europe, which means nomadic people. Tamilnadu is a home to various categories of gypsies, and among them the nomadic tribes or gypsy named as Koravar (or) Narikoravan (or) Kuruvikaran stands in the forefront. The occupation of Narikoravar community is mostly hunting jackals and other wild animals. Later, due to the government ban on possession of fire arms, the Narikoravar community changed their occupation to selling handicrafts. Narikoravar women has always taken a background role-subordinate to the figure of men as the "bread winner", and were shut away" in their family home. Comparing with women of other community, the Narikoravar women has more responsibilities that are imposed on her that resists her self-development. The plight of these women is mainly due to their upbringing in their family and culture. The nomadic nature of their culture, pose an obstacle for them to make a permanent income for their livelihood. They are economically poor and have engaged in self entrepreneurial business for their livelihood like selling fancy items, grocery items, soft toys making, ornaments and beads making etc. Even though they have an ability and skill in entrepreneurship business, they lack in upgrading their skills with technological enhancement. Hence, the researcher has focused on socio-economic conditions of the respondents, understanding the problems faced by women entrepreneurs and their awareness about government welfare schemes. The research also throws light on the status of women entrepreneurs, their economic status and their awareness about these schemes by employing appropriate statistical methods.
\end{abstract}

Keywords: Narikoravar Women, Entrepreneur, Problems of Entrepreneurship, Government Welfare Schemes

\section{INTRODUCTION}

The gypsies are an indigenous person whose main occupation was hunting but are also considered as one of the greatest bandit communities in south India. The word gypsies is derived from Europe, which means nomadic people. Most of the people are frightened of this community and are scornful to them. They are looked upon them with abhorrence and are considered dirty, due to their unusual pattern of living. They are more exploited and abused by the police, wherever they erect their dwelling. The reason for this distrustful position in the society may be due to their past as burglars. They are considered criminals and not given a chance to assimilate with society. They are also called as Koravar (or) Narikoravan (or) Kurivikaran in Tamil Nadu and scattered all over the state, due to their wandering routine.

As they lead a nomadic life they do not have a permanent home, but presently a large number of these people live in some more established surroundings. Their presence is visible in numerous villages and cities, but they continue their hereditary profession of hunting like their associates in the south. The society has yet to accept them, at least as mere human beings. This view point from the society and the governmental schemes for their development need to be stressed on a larger scale [1].

They live a life secluded from others and are most tenacious in following their customs and the rules that govern their clan. It is interesting to note that thesegypsy territories are self-contained as a community as any other caste in India. They are respected to a point as they are not of the lowest cast, but they are certainly feared. The gypsies have been included as a cast at a much later date in Indian History.

The occupation of Narikoravar community has been hunting jackals, and other wild animals. Later on Narikoravar community shifted their occupation into ornaments making, soft toys making etc. However, the Narikoravas have not been acknowledged as a scheduled tribe. The reason was that Narikoravars do not have a permanent settled life, and their children failed to attend schools. In orderto uplift the Narikoravar community, the state government has authorised a welfare board in May 2008, headed by the minister for backward classes and minority welfare. However the enrolment is very low and slow [2].

Refining them and guiding them into the conventional society is very important for assisting them to lead a dignified life. The need for the hour is the awareness of the demand for welfare board and including these communities in to schedule tribe category rather than the backward class. At present Narikoravar have been classified as Most Backward Class (MBC) in Tamil Nadu. 


\section{NARIKORAVAR WOMEN}

Narikoravar women has always taken a background rolesubordinate to the figure of men as the "bread winner", and were shut away" in their family home. Comparing with women of other community, the Narikoravar women has more responsibilities that are imposed on her that resists her self-development. The plight of these women is mainly due to their upbringing in their family and culture. The women of the gypsy community are considered to play a significant role in their family, though they are portrait as subordinate to men, as the state of any women in the patriarchal society. The girl child of this community is brought up to help in domestic chores and obey her father.

Emphasize should be brought on the women in this ethnic group as they play vital role in their home and in the upbringing of their children. They are responsible for the welfare and safekeeping of their family. The major functions carried out by women are restricted to the individual domestic sphere, which include looking after their husbands, parents, in-laws and their children. At very young age they are assigned tasks such as looking after their younger siblings, and doing a few chores. This shows the early training towards a woman's commitment to housework, housekeeping and looking after younger brothers and sisters.

Most gypsy women are married and conceive at early age. They dropout a formal education, and consequently give up developing themselves for a job. Women of these communities have an obligation and duty of attending to their homes, and are forced in joining the job market. However, due to their poor academic development, they are forced to accept precarious conditions and low wages without any complaints [3].

Women of these community desire to improve their quality of life by pursuing their own individual and collective emancipation. At the same time, their motive is to progress to liberation without opposing the male members of their ethnic group, nor try to disregard their family values. They strive to achieve progress by accepting their roles and circumstances as members of the gypsy culture, while also creating contexts in which their feminine figure, and identity are recognized without the slightest discrimination.

\section{REVIEW OF LITERATURE}

Kathryn Coe \& Jelena Čvorović (2017) conducted a study on "The health of Romanian Gypsy women in Serbia". The average age of the Gypsy women in this study was 43.5 (15.5\%); the majority of them were between 48 and 57 years of age. Many used the interview time to share stories about their marriages, children, and daily worries. Over half of the women who were interviewed $(53.7 \%)$ reported that they have never seen a doctor when they were ill [4].
Mara Zafiu (2017) - University of Pennsylvania, conducted a study on "Health Access for Vulnerable Groups: "Gypsy" Narikuravar Community in Tamil Nadu, India”. The sample of 51 women interviewed demonstrated patterns consistent with the ones known about the Narikuravar community. It stressed on a low educational attainment: 18 interviewed women never attended school, and only one went to school up to 12 standards, one had a Bachelor's degree and one had a Master's degree. However, the educational results of women were not different than those reported for the men in the family, signaling an overall lack of educational opportunity within the tribe, rather than a gender concern [5].

Jayachithra (2016) A considerable population of 1473 Narikuravar community is thriving in Palamalai Nagar, Sivagangai district. The pathetic condition is that they stay together with families of their married children in a single roomed house. Among the school going Narikuravar children only $30 \%$ to $40 \%$ show regular attendance. The dropout rate has been on an increase every year. As their earnings are not sufficient to fulfill their needs, they are forced to loan money from usury lenders and repayment poses a huge burden for people of these communities [6].

Senthilkumar (2004) conducted a study on "Living and working condition of gypsy community at Thimmampalayampudur, Karamadai Block" in Coimbatore District. Nearly 70 percent (68.33\%) of the respondents earn their living by making and selling fancy items. Above half (56.67\%) of the respondents are satisfied with their current occupation. A slightly more than half (51.67\%) of the respondents live in nuclear families. Majority $(71.67 \%)$ of the respondents have concrete houses. Nearly 70 percent (68.33\%) of the respondents also felt that they have accepted their social function. Nearly 70 percent (63.33\%) of the respondents get help from the society during incidence of various problems [7].

Jayaraman (2001) conducted a study on "Settled gypsy community" in Coimbatore. The major findings of this study were: all the respondents' social and conditions are economically very poor. All the respondents (100 percent) felt that they should obey the traditional panchayat rules and regulations. Majority (88.3 percent) of the respondent did not have any awareness on government welfare programmes [3].

Iyyappan (1992) conducted a study on "Socio economic conditions of Narikuravans" in Madras. The major findings of this study were that all the respondents' economic and social condition is very poor. A vast majority of the respondent (87.6\%) were engaged in both business and hunting. A good number (50\%) of the respondents know Gujarati language. While living in joint family system, 39.33 percent of respondents used gun for hunting and 70 percent of the respondents came from Gujarati community [8]. 


\section{OBJECTIVES OF THE STUDY}

The main objectives of the study are

1. To discover the socio-economic status of the respondents.

2. To recognize the issues confronted by women entrepreneurs.

3. To know their awareness about government welfare schemes of the respondents.

\section{RESEARCH METHODOLOGY}

The researcher has collected sufficient secondary data related to the study, and hence the researcher adopted descriptive research design for the present study. The Narikoravar community settled at Narikoravar colony in Thimmampalayam pudur, Karamadai block, Coimbatore district. The researcher exclusively selected Narikoravar colony in his study.

The colony comprise of 124 Narikoravar families. The population size is very small, so the researcher adopted census method of sampling, 124 is considered as universe for the present study. The researcher constructed self structure questions and adopted interview schedule as the tool for data collection. During the course of data collection 4 families were out of station, so the researcher was unable to collect their data. Hence, 120 is the sample size of the present study. Analysis of the data was done by appropriate statistical methods.

\section{RESULTS OF THE STUDY}

TABLE I AgE Wise RESPONDENTS

\begin{tabular}{|l|c|c|}
\hline \multicolumn{1}{|c|}{ Age } & Frequency & Percentage \\
\hline Below 29 years & 49 & $41 \%$ \\
\hline 30 to 46 years & 55 & $46 \%$ \\
\hline 47 years \& above & 16 & $13 \%$ \\
\hline Total & 120 & $100 \%$ \\
\hline
\end{tabular}

The Table I shows the age wise distribution of respondents. It is visible from the above table that the majority of respondents i.e., 55 (46\%) belong to the age group between 30 to 46 years, 49 (41\%) of the respondents age group is below 29 years and the rest $16(13 \%)$ of the respondents are in the age group of above 47 years.

TABLE II EDUCATION WISE DISTRIBUTION

\begin{tabular}{|l|c|c|}
\hline Educational status & Frequency & Percentage \\
\hline Illiterate & 64 & $53 \%$ \\
\hline Primary level & 26 & $22 \%$ \\
\hline Middle school level & 19 & $16 \%$ \\
\hline High School & 11 & $9 \%$ \\
\hline *Total & 120 & $100 \%$ \\
\hline
\end{tabular}

The data presented in Table II gives the education wise distribution of respondents. Out of total respondents (120), i.e., 64 (53\%) belong to illiterate, 26 (22\%) has received primary education, 19 (16\%) has received middle level and 11 (9\%) has received higher education. It is clearly reflected that among the total number of respondents illiterate dominated over the others.

TABLE III OCCUPATION WISE DISTRIBUTION

\begin{tabular}{|l|c|c|}
\hline \multicolumn{1}{|c|}{ Occupation } & Frequency & Percentage \\
\hline Grocery Items & 14 & $12 \%$ \\
\hline Fancy Items & 84 & $69 \%$ \\
\hline Tattoo & 3 & $3 \%$ \\
\hline Ornaments Making & 18 & $15 \%$ \\
\hline Fish Line & 1 & $1 \%$ \\
\hline Total & 120 & $100 \%$ \\
\hline
\end{tabular}

The data presented in the Table III gives the occupation wise distribution of the respondents. Out of total respondents (120), i.e., 84 (69\%) belongs to selling fancy items, 18 (15\%) Ornaments making, 14 (12\%) Grocery items, 3 (3\%) Tattoo and 1 (1\%) fish line. Considering the occupation of the respondents, the occupation that focussed on selling fancy items dominated over all the other categories of occupation.

TABLE IV FINANCIAL ISSUES

\begin{tabular}{|l|c|c|c|c|c|c|}
\hline \multicolumn{1}{|c|}{ Issues } & SA & A & N & D & SD & Total \\
\hline I was forced to borrow money to continue my business & $\begin{array}{c}106 \\
(88)\end{array}$ & $\begin{array}{c}10 \\
(8)\end{array}$ & $\begin{array}{c}2 \\
(2)\end{array}$ & $\begin{array}{c}0 \\
(0)\end{array}$ & $\begin{array}{c}2 \\
(2)\end{array}$ & \\
\hline Due to high interest rate on loans,savings is not possible & $\begin{array}{c}84 \\
(70)\end{array}$ & $\begin{array}{c}32 \\
(26)\end{array}$ & $\begin{array}{c}2 \\
(2)\end{array}$ & $\begin{array}{c}0 \\
(0)\end{array}$ & $\begin{array}{c}2 \\
(2)\end{array}$ & \multirow{2}{*}{$\begin{array}{c}120 \\
(100)\end{array}$} \\
\hline It is impossible to continue the business without borrowing & 62 & 48 & 7 & 0 & 3 \\
$(52)$ & $(40)$ & $(5)$ & $(0)$ & $(3)$ & $(100)$ \\
\hline Despite the high interest rate, we borrow money from usury lenders & $\begin{array}{c}44 \\
(37)\end{array}$ & $\begin{array}{c}47 \\
(39)\end{array}$ & $\begin{array}{c}12 \\
(10)\end{array}$ & $\begin{array}{c}5 \\
(4)\end{array}$ & $\begin{array}{c}12 \\
(10)\end{array}$ \\
\hline No one gives huge money for debt due to trust issues & $\begin{array}{c}47 \\
(39)\end{array}$ & $\begin{array}{c}15 \\
(27)\end{array}$ & $\begin{array}{c}8 \\
(13)\end{array}$ & $\begin{array}{c}17 \\
(7)\end{array}$ & $(14)$ & \\
\hline
\end{tabular}

Table IV depicts that Financial issues faced by the respondents. 88 percent of the respondents strongly agreed that they were in a position to borrow money for their business continuance, 70 percent of the respondents strongly agreed that they were facing the problem of paying high rate of interest, 52 percent of the respondents strongly 
agreed that it is impossible to continue the business without borrowing, 39 percent of the respondents agreed that they depended only on usury interest and the rest 39 percent of the respondents strongly agreed that people were reluctant to give huge money as debt.

TABLE V SOCIAL ISSUES

\begin{tabular}{|c|c|c|c|c|c|c|}
\hline Issues & SA & A & $\mathbf{N}$ & D & SD & Total \\
\hline The challenges of acquiring fake products with the same label & $\begin{array}{c}72 \\
(60)\end{array}$ & $\begin{array}{c}4 \\
(3)\end{array}$ & $\begin{array}{l}10 \\
(8)\end{array}$ & $\begin{array}{c}2 \\
(2)\end{array}$ & $\begin{array}{c}32 \\
(27)\end{array}$ & \multirow{5}{*}{$\begin{array}{c}120 \\
(100)\end{array}$} \\
\hline Lack of motivational responses from the customer & $\begin{array}{c}35 \\
(29)\end{array}$ & $\begin{array}{c}22 \\
(18)\end{array}$ & $\begin{array}{c}9 \\
(8) \\
\end{array}$ & $\begin{array}{c}6 \\
(5) \\
\end{array}$ & $\begin{array}{c}48 \\
(40) \\
\end{array}$ & \\
\hline No travel mobility and convenience & $\begin{array}{c}13 \\
(11)\end{array}$ & $\begin{array}{c}7 \\
(6)\end{array}$ & $\begin{array}{c}36 \\
(30) \\
\end{array}$ & $\begin{array}{c}6 \\
(5)\end{array}$ & $\begin{array}{c}58 \\
(48)\end{array}$ & \\
\hline Competition between women entrepreneurs & $\begin{array}{c}39 \\
(32) \\
\end{array}$ & $\begin{array}{c}31 \\
(26)\end{array}$ & $\begin{array}{c}18 \\
(15)\end{array}$ & $\begin{array}{c}2 \\
(2)\end{array}$ & $\begin{array}{c}30 \\
(25)\end{array}$ & \\
\hline Lack of publicity among competing market forces & $\begin{array}{c}34 \\
(28)\end{array}$ & $\begin{array}{c}24 \\
(20)\end{array}$ & $\begin{array}{c}22 \\
(19)\end{array}$ & $\begin{array}{c}6 \\
(5)\end{array}$ & $\begin{array}{c}34 \\
(28)\end{array}$ & \\
\hline
\end{tabular}

Table $\mathrm{V}$ explains that marketingissues confronted by the respondents. 60 percent of the respondents strongly agreed that they faced the challenges of acquiring fake products with the same label, 40 percent of the respondents strongly dis-agreed that there is a lack of motivational response from the consumer, 48 percent of the respondents strongly dis- agreed that they were not having travel mobility and convenience, 32 percent of the respondents strongly agreed that they face competition with other women entrepreneurs, and the rest 28 percent of the respondents have equally agreed and dis-agreed, that there was lack in publicity in the present marketing.

TABLE Vi MARKETING ISSUES

\begin{tabular}{|c|c|c|c|c|c|c|}
\hline Issues & SA & A & $\mathbf{N}$ & D & SD & Total \\
\hline A lack of appreciation for the traditional trade & $\begin{array}{c}78 \\
(65)\end{array}$ & $\begin{array}{c}4 \\
(3)\end{array}$ & $\begin{array}{c}7 \\
(6) \\
\end{array}$ & $\begin{array}{c}1 \\
(1)\end{array}$ & $\begin{array}{c}30 \\
(25) \\
\end{array}$ & \multirow{5}{*}{$\begin{array}{c}120 \\
(100)\end{array}$} \\
\hline The twin role of home and business & $\begin{array}{c}60 \\
(50)\end{array}$ & $\begin{array}{c}13 \\
(11)\end{array}$ & $\begin{array}{l}11 \\
(9)\end{array}$ & $\begin{array}{c}3 \\
(3)\end{array}$ & $\begin{array}{c}33 \\
(27)\end{array}$ & \\
\hline Male dominance is high & $\begin{array}{c}41 \\
(34)\end{array}$ & $\begin{array}{c}15 \\
(12)\end{array}$ & $\begin{array}{c}20 \\
(17)\end{array}$ & $\begin{array}{c}5 \\
(4)\end{array}$ & $\begin{array}{c}39 \\
\text { (33) }\end{array}$ & \\
\hline $\begin{array}{l}\text { In work place, other community women entrepreneurs are } \\
\text { taking decision authority, We cannot decide for ourselves } \\
\text { (Narikoravar community) }\end{array}$ & $\begin{array}{c}59 \\
(49)\end{array}$ & $\begin{array}{c}19 \\
(16)\end{array}$ & $\begin{array}{c}19 \\
(16)\end{array}$ & $\begin{array}{c}6 \\
(5)\end{array}$ & $\begin{array}{c}17 \\
(14)\end{array}$ & \\
\hline I am being harassed at the workplace & $\begin{array}{c}21 \\
(17)\end{array}$ & $\begin{array}{c}21 \\
(17)\end{array}$ & $\begin{array}{c}23 \\
(20)\end{array}$ & $\begin{array}{c}6 \\
(5)\end{array}$ & $\begin{array}{c}49 \\
(41)\end{array}$ & \\
\hline
\end{tabular}

Table VI explains that socialissues encountered by the respondents. 65 percent of the respondents strongly agreed that they faced the lack of appreciation in the family, 50 percent of the respondents strongly agreed that women entrepreneur play twin role in home and business, 34 percent of the respondents were strongly agreed that male dominance is high, 49 percent of the respondents strongly agreed that they are denied in taking decision, when compared with other women entrepreneurs in the work place, and the rest 41 percent of the respondents equally disagreed that they are being harassed in the workplace.

TABLE VII MARKETING ISSUES

\begin{tabular}{|c|c|c|c|c|c|c|}
\hline Issues & SA & A & $\mathbf{N}$ & D & SD & Total \\
\hline $\begin{array}{l}\text { When purchasing raw material, some products are damaged. } \\
\text { The dealers refused to replace the damaged product }\end{array}$ & $\begin{array}{l}101 \\
(84)\end{array}$ & $\begin{array}{c}6 \\
(5)\end{array}$ & $\begin{array}{c}0 \\
(0)\end{array}$ & $\begin{array}{c}0 \\
(0)\end{array}$ & $\begin{array}{c}13 \\
(11)\end{array}$ & \multirow{5}{*}{$\begin{array}{c}120 \\
(100)\end{array}$} \\
\hline Raw materials are not available on time & $\begin{array}{c}63 \\
(52)\end{array}$ & $\begin{array}{c}19 \\
(16)\end{array}$ & $\begin{array}{c}13 \\
(11)\end{array}$ & $\begin{array}{c}4 \\
(3)\end{array}$ & $\begin{array}{c}21 \\
(18)\end{array}$ & \\
\hline $\begin{array}{l}\text { There is no continuous supply of raw materials, thus } \\
\text { affecting the business }\end{array}$ & $\begin{array}{c}40 \\
(33)\end{array}$ & $\begin{array}{c}26 \\
(22)\end{array}$ & $\begin{array}{c}27 \\
(23)\end{array}$ & $\begin{array}{c}3 \\
(2)\end{array}$ & $\begin{array}{c}24 \\
(20)\end{array}$ & \\
\hline $\begin{array}{l}\text { Due to delay in supply of raw materials, it is not possible for } \\
\text { making and selling the product on time }\end{array}$ & $\begin{array}{c}42 \\
(35)\end{array}$ & $\begin{array}{c}33 \\
(27)\end{array}$ & $\begin{array}{c}19 \\
(16)\end{array}$ & $\begin{array}{c}7 \\
(6)\end{array}$ & $\begin{array}{c}19 \\
(16)\end{array}$ & \\
\hline $\begin{array}{l}\text { Due to variations in the price of raw materials, the price of } \\
\text { the commodity cannot be determined satisfactorily }\end{array}$ & $\begin{array}{c}50 \\
(42)\end{array}$ & $\begin{array}{c}28 \\
(23)\end{array}$ & $\begin{array}{c}18 \\
(15)\end{array}$ & $\begin{array}{c}8 \\
(7)\end{array}$ & $\begin{array}{c}16 \\
(13)\end{array}$ & \\
\hline
\end{tabular}

Table VII explains the issues of acquiring raw material issues faced by the respondents. 84 percent of the respondents strongly agreed that they faced problems while purchasing raw materials (some products are damaged, the 
dealers refused to change the product and not ready to replace the damaged product), 52 percent of the respondents strongly agreed that raw materials are not available in time, 33 percent of the respondents strongly agreed that there was no continuous supply of raw materials, thus affecting the business, 35 percent of the respondents strongly agreed that there was delay in supply of raw materials hence it was not possible for themaking the product on time and the rest of 42 percent of the respondents strongly agreed that variations in the price of raw materials leads to unableness of finding the price of the commodity.

TABle ViII ATtending Home Ceremonies Of OTHER COMMUNities

\begin{tabular}{|l|c|c|}
\hline $\begin{array}{c}\text { Attending other } \\
\text { community home } \\
\text { ceremony }\end{array}$ & Frequency & Percentage \\
\hline Always & 21 & 18 \\
\hline Occasionally & 65 & 54 \\
\hline Never & 34 & 28 \\
\hline Total & 120 & 100 \\
\hline
\end{tabular}

Table VIII reveals the engaging in home ceremony of other communities among Narikoravar community. 54 percent of the respondents attending home ceremony occasionally, 28 percent of the respondents never attended home ceremonies of other communities, and the remaining 18 percent of the respondents were always attending the home ceremony of other communities.

TABLE IX SOCIAL ISSUES OF OTHER COMMUNITIES

\begin{tabular}{|l|c|c|}
\hline $\begin{array}{c}\text { Engaging Social } \\
\text { issues with other } \\
\text { community }\end{array}$ & Frequency & Percentage \\
\hline Always & 23 & 19 \\
\hline Occasionally & 48 & 40 \\
\hline Never & 49 & 41 \\
\hline Total & 120 & 100 \\
\hline
\end{tabular}

Table IX explains the engaging in social issues with other community among Narikoravar community. 41 percent of the respondents never engaged in such social issues, 40 percent of the respondents engaged occasionally, and 19 percent of the respondents engaged always in social issues.

TABle X AWAREness About Welfare SCHEMES

\begin{tabular}{|l|c|c|}
\hline Welfare Schemes & Frequency & Percentage \\
\hline Aware & 75 & 62 \\
\hline Not Aware & 45 & 38 \\
\hline Total & 120 & 100 \\
\hline
\end{tabular}

Table $\mathrm{X}$ explains that 62 percent of the respondents are aware about social welfare schemes and the remaining 38 percent of the respondents are not aware about social welfare schemes.
Table Xi Sources Of KNOWLedge About Welfare Schemes

\begin{tabular}{|l|c|c|}
\hline \multicolumn{1}{|c|}{ Sources } & Frequency & Percentage \\
\hline Friends & 51 & 68 \\
\hline Relatives & 2 & 3 \\
\hline Social worker & 2 & 3 \\
\hline SHG Members & 18 & 23 \\
\hline Village Leader & 2 & 3 \\
\hline Total & 120 & 100 \\
\hline
\end{tabular}

Table XI points out the sources of information about welfare schemes. 68 percent of the respondents received the information from friends, 23 percent of the respondents received information from SHG members, 3 percent of the respondents received information from relatives, social worker and village leader.

\section{RESULTS AND DISCUSSION}

Out of 120 respondents i.e., 55 (46\%) belongs to the age group between 30 to 46 years. The women of gypsy community settled in this particular area, started their entrepreneurship from the age of 30 due to their family restrictions. That's why the results show most of the age group between 30 to 46 years. The study reveals that 64 (53\%) respondents' are illiterate due to their nomadic culture, and their inability to avail permanent education. Out of 120 respondents i.e., 84 (69\%) occupation have been selling fancy items which gives more profit comparing to selling other items.

Even though the other respondents were undertook those occupation due to the low investment. Majority of the respondents 101 (88\%) strongly agreed that they are in a position to borrow money for business. It is a seasonal employment/business comparing of other businesses. They are able to earn money only at the time of temple festival, religious occasions etc. They are in a situation to borrow money, as it requires more investment to the business. Above half (60\%) of the respondents strongly agreed that they faced the challenges of fake products with the same label.

Narikoravar has been making hand made beaded ornaments, while the other businessman makes the machinery products with polish and mixed their products in to Narikoravar handmade products. Hence, they had are forced to compete with the fake products. Majority (84\%) of the respondents strongly agreed that they faced challenges while purchasing raw material and problems like not able to replace damaged products from their dealers. The wholesale dealers took advantage of the ignorance and innocence of the gypsy entrepreneurs and cheated them with damaged products. Above half (54\%) of the respondents attending home ceremonies occasionally andNearly half (41\%) of the respondents never engaged themselves in social issues. 
This shows that Narikoravar community has a separate settlement area secluded from other people within the same territory. They do not engage or attach themselves with the other community people, and are mostly reluctant to invite them to their function. But if they were invited, they might be ready to participate in the other community functions as well. Nearly 70 percent (62\%) of the respondents were aware about social welfare schemes, and nearly 70 percent (68\%) of the respondents received information from friends about welfare schemes. Narikoravar community only knows Self Help Groups (SHG) which is specialised for providing loan with low rate of interest, exclusively for women. They were not aware of other welfare schemes.

\section{CONCLUSION}

The ultimate aim of every soul in this world is to have happiness in life. The researcher concludes from the study that the Narikoravar people culture and tradition are changed but their way of dress, talk, occupation depict they are Narikoravar. The children in the committee areunable to continue their education due to the non availability of educationalscholarship reaching them on time, and the communities inability to provide sufficient financial help for higher education. Narikoravar women facing many problems in entrepreneurship, and they followtraditional occupation and train their children in the same. So many children are not able to acquire education due to their lack of interest and poor economic conditions with in the family. Very few Narikoravar women know only SHG programme and the remaining schemes do not reached them properly due to their nomadic nature of living. They also lack proper housing, toilet and drainage facility. So, the government should take necessary steps to improve their entrepreneurship and their sustainable development of their family.

\section{REFERENCES}

[1] Sunil, Bhuvaneswari. (2019). Narikuravar Women LifeMarginalisation and Access to Safe Abortion. Mumbai, India. Retrieved from https://www.researchgate.net/publication/332570 861_Marginalisation_and_Access_to_Safe_Abortion_Bhuvaneswari_ Sunil_4

[2] Llorent Bedmar, Vicente \& Torres León, Nazaret. (2012). Lifelong Learning of Gypsy Women in Spain. Procedia - Social and Behavioral Sciences, 48, 3119-3123. Retrieved from https://www. researchgate.net/publication/271396191_Lifelong_Learning_of_Gyps y_Women_in_Spain/fulltext/55e0debf08aecb1a7cc5a5de/271396191 _Lifelong_Learning_of_Gypsy_Women_in_Spain.pdf?origin=public ation_detail

[3] Jayaraman, A. (2001). A study on Settled Gypsy Community. Coimbatore, Tamil Nadu: India.

[4] Kathryn Coe \& Jelena Čvorović. (2017). The health of Romanian Gypsy women in Serbia.

[5] Mara Zafiu. (2017). Health Access for Vulnerable Groups: "Gypsy” Narikurava Community in Tamilnadu, India. University of Pennsylvania.

[6] Jayachithra (2016). Life style of the Narikuravar community, Palamalai Nagar, Sivagangai district.

[7] Senthilkumar. (2004). Living and working condition of gypsy community

Thimmampalayam pudur, Karamadai Block, in Coimbatore District.

[8] Iyyappan. (1992). Socio economic conditions of Narikuravans, in Madras. 